\title{
Bathing and Domination in the Early Modern Atlantic World
}

"From this place we could likewise see the three causeways which led into Mexico - that from Iztapalapan, by which we had entered the city four days ago; that from Tlacupa, along which we took our flight eight months after, when we were beaten out of the city by the new monarch Cuitlahuatzin; the third was that of Tepeaquilla. We also observed the aqueduct which ran from Chapultepec, and provided the whole town with sweet water. We could also distinctly see the bridges across the openings, by which these causeways were intersected, and through which the waters of the lake ebbed and flowed. The lake itself was crowded with canoes, which were bringing provisions, manufactures, and other merchandise to the city. From here we also discovered that the only communication of the houses in this city, and of all the other towns built in the lake, was by means of drawbridges or canoes. In all these towns the beautiful white plastered temples rose above the smaller ones, like so many towers and castles in our Spanish towns, and this, it may be imagined, was a splendid sight."

-Bernal Díaz del Castillo

Source: Díaz del Castillo [1568] 1844.

The Spaniards were astonished. The city they entered was clean and orderly, with enormous bustling markets, wide streets and plazas, huge pyramids, and other impressive feats of engineering. In some ways their descriptions recalled the early modern Iberian cities they knew, with white-plastered monumental architecture, peasants and nobles, and thriving regional economies. Unsettling the comparisons 
at a fundamental level, however, was the fact that Tenochtitlán was an aquatic city, built to float at the edge of land and water, different from those of the semi-arid landscapes back home. Díaz del Castillo's perspective on this city in the lake was gained from the top of the Templo Mayor-the main ceremonial pyramid-on November 12, 1519, and was recounted in Spain in 1568, a lifetime after the Spaniards conquered the Mexica rulers and subjected the people. Much of the wonder of the experience had faded by the time of the retelling, and what remained was a strategic, military perspective that identified the important points of control over the watery milieu: drawbridges, aqueducts, and causeways. In the twenty-one months that followed the visit to Moctezuma's palace, these crucial infrastructures were destroyed by the Spanish and their allies. The domination of the lacustrine capital of the Mexica empire was not simply a military campaign, however, and it did not end in 1521. Over the centuries that followed a slow siege was laid on the underlying relationship between the waters of the Valley of Mexico and the human, built environment. The pre-Hispanic water culture-infrastructures, ideas, and practicesthat formed as an adaptation to that place was drastically reshaped in the ongoing crucible of conquest.

In this chapter I trace the long process of change in the water cultures of Mesoamerica by focusing on struggles over bathing-over the direct, intimate, bodily contact between people and waters. I focus here on central, highland Mesoamerica, especially the Valley of Mexico, because it was the most densely populated area, with many hot and mineral springs and substantial historical documentation. It is, however, only one region of what is today Mexico, and although much of this book is focused on this region, we shall see in later chapters that people in other places bathed and otherwise engaged with mineral springs and waters in different ways. Bathing is a topic of inquiry that has not been explored in Mexican history, partly because documentation of this aspect of water culture is scant, but also because Díaz del Castillo's gaze from the top of the Templo Mayor reveals a blindness shared with scholars-even environmental historians-to the most common, quotidian interactions with water. This absence is created by the overwhelming presence in the literature of more strategic questions of hydraulic infrastructure and state formation. The literature on water has lavished attention on irrigation and agriculture, but proportionally few people in the long history of Mexico irrigated anything. Bathing and washing, on the other hand, are the common contacts with water that most people in the world have, including those who build, manage, and operate irrigation systems.

The verb "to bathe" signifies, at the very least, a contact between the body and water, or some other substance that behaves in a similar way, such as sun, dust, or light. When used to talk about water, the word can signify a range of different encounters with the liquid. Usually, in today's English, bathing is thought of as an act of cleaning one's body in water, or simply washing parts of one's body with water. Bathing can mean immersion in a tub of hot or cold water, using a wet 
cloth or sponge to clean the entire body or parts of it, standing under a shower, or even sitting in a room filled with steam. Immersion or other contact with water that does not involve soap or shampoo is less commonly conceived of as bathing, but actively swimming or diving through water, or simply lounging about in water, is sometimes also described as bathing, as the term "bathing suit" attests. In today's Spanish, these overlaps are similarly evident, as the verb to bathe (bañar) is frequently used to talk about immersion in the ocean or the swimming pool. The physical activity of swimming for exercise is now more often denoted by the verb "to swim" (nadar). Bathing in steam, a common practice throughout the Mediterranean world, Scandinavia, and Eastern Europe, was also the principal form of bath for the people of Mexico before and after conquest, all the way up to the nineteenth century. This Mesoamerican steambath-the temazcal-was called a baño or "bath" throughout the colonial and national periods, and the bathhouses, or baños, of Mexico would usually include tubs for immersion as well as a temazcal. At different moments in different places, these meanings and practices blurred even more than they do today.

\title{
TENOCHTITLÁN: THE CITY IN THE LAKE
}

\author{
"The whole body of the city is in the water." \\ -Francisco López de Gómara
}

Source: López de Gómara [1552] 1966: 147.

The Spaniards concentrated themselves and their activity in the highland plateau of what is today central Mexico, especially the lake-filled Valley of Mexico, home of the Aztecs. During much of the twentieth century Mexico City held the title of most populated metropolis in the world, stretching over nine hundred square miles in a valley surrounded by mountains. Apart from the rainy season between June and August, it is dry. There are some parks and open spaces, including wetlands and lakes near the airport to the east, and in the south in Xochimilco and Chalco. These watery zones, and the fact that parts of the city flood regularly during the rainy season, are reminders that this most urban of spaces was once a vast shallow lake fed by rivers coursing down the slopes that surround the city center. Place names also signal the hydraulic foundations of the city. Santa Maria la Ribera, for example, a neighborhood northwest of the downtown, was on the shore of the lake until the nineteenth century (ribera means "shore" or "bank"). Many roads were built on top of rivers that were turned into drainage tunnels as the city grew: Río Magdalena; Río Churubusco; Río de la Piedad. The waters 
themselves are hard to find now, as invisible as those tunnels that channel the huge volume of water falling as rain each summer northward out of the Valley of Mexico to the Río Tula. This enormous drainage project demands its opposite: an equally monumental system that brings a flood of freshwater to the city's pipes and faucets from hundreds of kilometers away and a kilometer downhill.

During the few centuries before Díaz del Castillo stood on top of the Templo Mayor, a water culture evolved in the Valley of Mexico that was fundamentally unlike that which we know today. The inhabitants adapted to living in a lake by building a highly productive agricultural system of raised-bed fields (chinampas) on the shores and shallows of the lake that enabled three harvests of the principal crops - maize, beans, and squash — by maintaining moist soil through the long dry season. Remnants of these fabled "floating gardens" can still be found operating in the southern end of Mexico City, in Xochimilco and Chalco. The plains and hills that surrounded the lake were dry-farmed during the rainy season, or supported with irrigation through the construction of dams and canals for surface waters and shallow wells for groundwater. ${ }^{1}$ The chinampas were also used as nurseries to produce seedlings that were transplanted to fields farther from the lake once the rainy season commenced. ${ }^{2}$ The lake itself-shallow, warm, and bathed in tropical sunshine-was enormously productive, providing all sorts of food and other useful materials, and hunting, fishing, and gathering these resources continued to supply much of the animal protein and other important nutrients up through the nineteenth century, as well as raw materials used to produce baskets and mats, the roofs of peasant houses, and many other household objects. ${ }^{3}$

The surplus generated by these activities supported population growth, urbanization, the constitution of political, warrior, artisan, and intellectual classes, and the creation of an empire. ${ }^{4}$ The Aztecs formed out of an alliance between the Mexica who had settled on the island of Tenochtitlán (where the historic center of Mexico City is today) in 1325, and their less-powerful partners in Texcoco and Tlacopan. Together they could mobilize upward of a hundred thousand soldiers, and thus were able to defeat the lord of Azcapotzalco in 1428 and dominate the Valley of Mexico until the Spanish arrived in 1520. The Aztecs, and especially the rulers of Texcoco, were skilled hydraulic engineers who mobilized the same masses of subjects who fought as soldiers to build dikes and causeways with roads that complemented a network of shallow channels dug into the lakebed to facilitate canoe traffic. 5 The island-city of Tenochtitlán reached a population of eighty thousand people at its height, fed and supplied by the lake and by the subjects of its far-flung empire.

Water is unpredictable and powerful. As the city of Tenochtitlán grew, it responded to the destructive behaviors of the lake with increasingly sophisticated engineering works that did not so much seek to eliminate the water as tame it. In the 1440 s floods ravaged the city, driving the rulers to take dramatic measures to protect it from further inundations. In response to the 1446 flood the ground level 
of the city center, with its ceremonial buildings, was raised by the city's residents about two meters, and in 1449 Nezahualcóyotl, the ruler of Texcoco who was allied with Moctezuma Ilhuicamina, the ruler of Tenochtitlán, designed and built an enormous earthen levee across the entire lake, protecting the city as well as the rich agricultural lands and the fresh waters of the western shore from the salty waters that surged into the eastern end of the lake. ${ }^{6}$ This dike, known as the Albarrada de Nezahualcóyotl, was 10 feet high and almost 25 feet wide, and stretched from north to south for some 16 kilometers-an especially mind-boggling achievement considering there were no beasts of burden in Mesoamerica to do the heavy lifting. At the same time that these building techniques kept lakewater out of the city and fields, they also supplied Tenochtitlán with clean water. In 1426 the Mexica ordered the construction of a raised, two-channel aqueduct that crossed the lake from the Chapultepec springs. 7 They relied upon the expertise of Nezahualcóyotl and his fellow architects from Texcoco, who shortly before the Spanish arrived built an irrigation system in the eastern foothills that extended some twenty kilometers and bound five towns together with shared infrastructure and managerial institutions. ${ }^{8}$ The enormous amount of social labor required for all these infrastructural works was commanded through compulsory tribute obligations, which led some scholars to consider the Aztec empire a form of "irrigation civilization" similar to those in ancient Egypt, China, and Mesopotamia, where water was controlled by a supremely powerful state. ${ }^{9}$

Our understanding of large-scale processes of infrastructure construction, agriculture, urbanization, and state formation in the Valley of Mexico before conquest is relatively solid; we know much less about the daily activities that formed the substance of those processes. People literally lived in and on the water. The buildings in some of the villages on the lakeshore, such as Coyoacan and Iztapalapa, were built on stilts so that the rising and receding lake waters could pass beneath them. The seasons were marked by the ebb and flow of the lake as it filled with rain and dried again, the life cycles of the flora and fauna that lived in the lake, and the livelihood practices that depended on that water. Hunting, fishing, and collecting provided much of the animal protein, often in the form of insects and their larva, as well as materials for houses and household objects. ${ }^{10}$ Salt, a key necessity for the largely vegetable diet, was extracted from the salt flats on the eastern shores of the lake by washing the soil and boiling the resulting brine.

The commingling of land and water in the Valley of Mexico was mirrored in the ideas and beliefs of the people. The indigenous people in the central highlands of Mexico, and throughout Mesoamerica, shared a complicated understanding of the constitution and order of the universe, and the place of people in it. In this "cosmovision" the land was considered to be surrounded by water far to the east and west, and water filled the depths underneath the land. ${ }^{11}$ The hills were permeated with water, and the springs and rivers that sprung forth from that watery land were met by the celestial waters of the rain. The god Tlaloc ruled over this 
watery underworld realm, as well as the lightning, thunder, and rain that were generated by the mountainous heights and fell from the skies above. Water was both the source of life and fertility as well as a worrisome and destructive force, whose complacence sometimes required the sacrifice of children. This cosmovision mapped onto the experience of living in the landscape of lakes, islands, wetlands, and canals of the Valley of Mexico.

The fields, towns, and cities of the Valley of Mexico were saturated with lakewater, and wading, swimming, and diving were daily activities. ${ }^{12}$ There are few comments about these kinds of activities by Spanish or Indian chroniclers, however. During the conquest and early colonial period the Spanish observers noticed the cleanliness of the people and the cities, and the frequent washing and bathing of all ranks of people. The cities of Tenochtitlán and Texcoco built urban water systems for public use, and in the streets of Tenochtitlán there were public latrines. Chroniclers of the conquest of Tenochtitlán remarked upon the orderliness, amplitude, and particularly the cleanliness of the public spaces, where human waste was collected and transported to the agricultural fields so that agricultural production was increased and little sewage entered directly into the water. ${ }^{13}$ The houses of the small noble class in Tenochtitlán were plumbed for water, and in Moctezuma's palace there was a "beautiful fountain with lots of water that flowed through underground pipes to other parts of the house." ${ }^{14}$ The houses of the elite also featured private steambaths, or temazcales, and the commoners made use of public ones built by the rulers. ${ }^{15}$ While people may have washed their hands or other body parts in cold water, bathing for hygiene, cleanliness, and ceremonial reasons took place in these temazcales. For drinking, clean water from the aqueduct was collected in canoes, or from the fountains, and sold by water merchants. In this water culture, extensive hydraulic infrastructures encouraged a wide range of uses and intimate daily contacts with water, an experience organized by elaborate ideas and concepts ranging from sophisticated knowledge of the qualities of different kinds of water and their effects on agriculture, to a deeply felt respect for maintaining the cleanliness of both their bodies and the lakewater around them.

\section{BATHING IN THE MEDITERRANEAN WORLD}

It is clear that the practices, meanings, and infrastructures of bathing in Mexico today are products of a long encounter between Europe and America, and water cultures in Tenochtitlán in 1490, on the eve of contact, were not the same as those in Andalusia. But while the conquest of the Americas was obviously an antagonistic meeting between people of two continents with no prior contact, to understand how the fusion of the two transpired it is essential to remember that on both sides of the encounter the peoples and cultures were already fusions of many earlier encounters. Furthermore, portraying Mexican water cultures as a colonial fusion of "Spanish" and "indigenous" directs attention away from the enormous changes 
that occurred between 1492 and the present day, in favor of the curation of hypostasized cultural survivals. Rather than cast Mexican water cultures in Mexico as the mixing, or mestizaje, of some fixed set of European bathing traits on the one hand and those of indigenous "deep Mexico" ${ }^{16}$ on the other, I will start by showing how those traditions were already products of previous encounters. We have seen, for example, how the Mexica incorporated the engineering expertise of Nezahualcóyotl and other Texcocans in building Tenochtitlán, the city in the lake. In this section I argue that the colonial bathing encounter was shaped in important ways by the deep religious and cultural conflicts in Iberia during the fifteenth and sixteenth centuries.

The general contours of the culture of bathing in Spain and the rest of modern Europe and the Mediterranean were established by the Romans, who carried a standard set of practices and infrastructures throughout the Near East, North Africa, and Europe, which, long after the fall of that empire, continued to be reshaped and reproduced. The Roman bath included different rooms with hot, warm, and cold pools of water, as well as dressing rooms and steam rooms, and these different baths served different purposes in line with specific conceptions of human health and biology. Hot pools and steambaths were believed to open the pores of the skin and allow the transpiration of unwanted substances from the body; cold water closed the pores again. Under the advice of a doctor, bathing in the correct kinds and temperatures of water exercised a positive influence on the humors of the body, correcting for imbalances. Going to the bath, or bathing, could mean swimming or lounging in any temperature of water or soaking up the humid heat of the steam room, a wide array of different contacts with water that continue to define bathing today. The waters themselves were also varied, as Roman baths utilized both thermal mineral springs as well as freshwater sources heated artificially. The particular qualities of all these different waters were appreciated for their therapeutic effects, and mineral waters were valued as powerful curative agents. ${ }^{17}$

The Roman baths were social centers, and many of the activities of daily life were carried out within their walls. People gossiped, ate food, exercised and played games, had sex, relaxed, hatched plans, and carried out affairs of business and government. By bringing wealthy and powerful men together, the baths were settings for the consolidation of the patrician class. At its zenith of wealth and power the city of Rome counted more than four hundred bathhouses, and there were hundreds if not thousands more scattered throughout the empire. Each of the mineral water spas was known for the particular properties of its waters and their curative uses. ${ }^{18}$ The sociality of bathing in the Roman world also involved religious or spiritual dimensions, and baths were dedicated to gods of both the Romans and those they subjugated. ${ }^{19}$ Roman towns throughout the empire were built on existing indigenous settlements with springs that held religious and social significance. The Roman baths in Bath, England, for example, were named "Aquae Sulis" in 
dedication to Sulis-Minerva, a hybrid entity that fused the Roman god of wisdom with what was most likely a water deity of western England, on the far edge of empire.

Water culture in the Iberian Peninsula was not a pure cultural product, waiting to be carried to an encounter with "indigenous" bathing in the Americas, but rather a continually changing, multistranded "selective tradition." ${ }^{\circ 0}$ The Arabs played an especially important role in this process, rebuilding and conserving many baths in Europe and the Mediterranean world built on hot springs. They were experts in hydraulic engineering, and during the High Middle Ages ("baja edad media": eleventh to fifteenth centuries) when they governed the Iberian Peninsula they constructed more sophisticated and remarkably more extensive urban and rural water infrastructure than had previously existed. Bathhouses were common throughout the Arab world, and this of course extended throughout Spain. Contrary to some popular ideas about the medieval period, bathing and bathhouses continued to exist in Europe and enjoyed a resurgence in the tenth to twelfth centuries. ${ }^{21}$ The baths of Barcelona, for example, were founded by the Arabs long before they passed into the hands of the Christian nobility, while the baths in Gerona were founded anew in 1194. Córdoba, the capital of the western Caliphate, was said to have nine hundred baths for eight hundred thousand inhabitants. ${ }^{22}$ In Spain, Arabs inherited and advanced the legacy of Greek and Roman literature, medicine, and cultural practices, conserving those works and codifying bathing culture in Islamic religious practice. ${ }^{23}$ The Ottomans, who ruled much of southeastern Europe and the eastern Mediterranean between 1300 and 1900, also reproduced and reshaped bathing practices and ideas, built bathhouses, and generated further borderlands bathing encounters.

\section{THE ECLIPSE OF BATHING IN SPAIN, 1500-1600}

The selective tradition of bathing in Iberia was forged in a context of prolonged religious and political conflict between Muslims and Christians. Bathing in medieval Spain was supported by a body of medical literature that came from GrecoRoman and Arab traditions and reproduced the organization of the bath around the Roman model with the cold room, warm room, hot room, dressing room, and resting room. Within the medical model elaborated by the Roman physician Galen, to which most doctors adhered well into the eighteenth century, bathing was important for carrying off the remains of digestion, which formed one of six groups of things - called "non-natural" or "necessary" things-that were not intrinsic to human bodies. Bathing, exercise, and sex, all of which produced sweat and the emission of fluids, eliminated the remnants of these things from the body, and following Aristotle, balance and moderation was considered the correct way to deal with them. ${ }^{24}$ Arab scholars such as Avicenna, who carried forth the Roman and Greek intellectual traditions in medieval Spain, delineated four 
kinds of baths-freshwater, seawater, hot springs, and steambaths. Medieval doctors described the effects and uses of different waters, such as sulfurous or ferruginous (iron) springs, and the only proscription to bathing came from those doctors who argued that very hot steambaths were dangerous because they disrupted the humors. In Arab Spain there was a good deal of tolerance and coordination among different groups to enable access by all to the bathhouses. In the baths of Castille, women and men bathed on alternate days, with Jews bathing on Fridays and Sundays. ${ }^{25}$ Similar schemes to enable access to baths by different groups in pluricultural societies were common in the Mediterranean world until the twentieth century, especially in bathhouses that utilized hot springs, which are by nature singular and limited sources that cannot be multiplied or expanded. ${ }^{26}$

Then, in the sixteenth century, people in Spain stopped bathing. María José Ruiz Somavilla has argued that understandings of cleanliness and bathing underwent a fundamental adjustment at this time, due to two kinds of historical factors. ${ }^{27}$ First, Christians only recently finalized the long struggle with Arab rulers over the Iberian Peninsula-the Reconquista - and distrust and hostility by Christians toward Muslims and Jews generated over centuries was codified under Christian hegemony as forced religious conversions, laws forbidding suspect activities, and the policing of customs by the Inquisition. At the beginning of the sixteenth century bathing institutions passed from Arab to Christian control, as was the case for the fifty bathhouses in Malaga that were given by the conquering Catholic kings to the Church. ${ }^{28}$ Soon, however, these bathhouses and the very practice of bathing came under scrutiny for they were linked to the customs of "infidels," who according to the racial concepts at the time were compelled to bathe by "inherited blood." ${ }^{29}$ Abstinence from bathing, by this same logic, was evidence of Christian ancestry and a badge of purity. Converts, or "new Christians," were banned from working in the bathhouses in 1527 , and by 1567 these attitudes toward bathing hardened into a decree forbidding bathhouses and bathing in Granada.

Following the legal measures against bathing and bathers, people were brought before the Tribunal of the Inquisition, tortured and punished, under accusations of bathing or even for being too clean. The suspects were often women, and from the declarations before the tribunal, it seems that what excited the imaginations of Christian men was the combination of hot water and nudity. ${ }^{30}$ Moorish men, however, did not escape persecution for bathing. Bartolomé Sánchez, for example, confessed to bathing in 1597 and was imprisoned with loss of all property. Miguel Cañete, a gardener, was tried and tortured in 1606 under the accusation that he washed in the fields where he was working. ${ }^{31}$ The rejection of bathing in the sixteenth century, although enforced by capital punishment, was never total, and bathhouses remained open in many parts of Spain until the prohibition of 1567. Even with the prohibition, bathhouses in Andalusia remained open and bathing in private seems to have continued or perhaps even increased in inverse proportion to the reduction of public bathing. Furthermore, accusations of heresy were 
directed most often at those known or suspected to be Jews, Muslims, or recent converts to Christianity, and so bathing was not as risky a proposal for others. Most likely it was those unimpeachable Christians who were seen returning to the water in the early 1600 , bathing publicly, in groups, in cold rivers and streams. Although it was more acceptable and visible by that point, people probably never fully stopped swimming and bathing in rivers and springs during the second half of the sixteenth century, despite the prohibitory attitudes and decrees.

Sexuality and morality were an area of anxiety associated with bathing, and ideas of health were closely related to those about masculinity, custom, and nature. The health of an individual was maintained through balance and moderation in one's customs (costumbres), for customary behaviors were considered indissociable from an individual's "nature." ${ }^{2}$ In this deeply conservative perspective, health was attained by avoiding excess (deleite) and disordered appetites, for balanced and moderate habits resulted in a healthful physiological character. Nature/ custom was considered to be the best doctor, and the best remedies for ailments were to be found in nature and good customs. In this conceptual universe, bathing one's entire body by immersion in hot water or steam was easily construed as an extreme act and thus a problem. The virility of men, in particular, was seen to diminish from bathing, an idea that Ruíz Somavilla attributes in part to the idea that men had sex with men in bathhouses. The larger fear, rooted in a concatenation of moral norms concerning religion, sex, gender, and citizenship, was, as Fadrique Enríquez wrote at the time, that in the baths the soldiers of Christendom "would be made accustomed to luxury, delicate and vice-ridden, unhealthy ... skinny, without virtue, cowardly and fearful." 33

The second set of sociohistorical factors that were driving a slow reconceptualization of bathing and cleanliness among intellectuals had to do with the incipient formation of merchant capital and the spread of Renaissance thought. As European powers reached out to control far-flung empires, trade networks, and colonies during the sixteenth century, the merchants who made fortunes from this new global trade formed a social group that did not fit into the old regime of peasants, artisans, nobles, and church. While not nobles, the emergent bourgeoisie wielded the economic power to consume the array of commodities that were captured by global webs of trade in the early modern world. The increasingly important idea that men should maintain balance in their customs and not overindulge in food, drink, sleep, sex, and other pleasures can also be read as a warning to the new bourgeoisie, and to those who sought to emulate their customs. ${ }^{34}$ At the same time, the medieval belief that social status was inherited through lineage- "purity of blood"-became more flexible and elite social status required more visible proof in the form of material culture and customs. Cleanliness was one area in which social, moral, religious, and class distinctions were established. While full-body bathing was unacceptable in sixteenth-century Spain, keeping one's hands and face clean took on an increasingly important role. The lightness of the visible parts 
of the body, maintained by washing, was seen as a sign of purity of blood, and placed the bather beyond reproach.

The abolition of bathhouses and many forms of bathing put doctors in a difficult bind. They continued to read and respect the foundational works of Pliny, Aristotle, Galen, and other classical and medieval scholars who recommended bathing for curing diseases and maintaining healthfulness, but these ideas were increasingly at odds with the political culture of the time. Doctors resolved this contradiction by arguing that the bathing activities of the Romans and Greeks had healing properties in antiquity but not in the present. Thus bathing actually did have benefits, but the damage caused by any abrupt change in custom was greater than the benefit that could be gained by adopting bathing practices anew. The long-accepted idea that bathing was good because it opened the pores of the skin and allowed for "exhalation" of unwanted substances, was turned around to argue for the threat of contagion from the environment entering through those same open pores. The malleability to the point of outright incoherence given to medical concepts so that they would correspond to the social field of forces in the sixteenth century prompted one scholar of the topic to characterize attitudes and ideas about bathing as "ideological." 35

Changes in ideas about bathing were accompanied by changes in practices. Full-body immersion and steambaths were viewed with suspicion throughout Europe. Instead, people engaged in a more limited washing of the face and hands, as well as the practice of "dry bathing," which was the changing, and washing, of linens, rather than the body itself. "Dry bathing" - the washing of underwear, really-eliminated the body's "exhalations" that were captured by undergarments. Among the wealthy, undergarments became far more conspicuous during this time, protruding from sleeves and collars as a display of the hygienic customsand social status-of the wearer. ${ }^{36}$

Eventually in the seventeenth century bathing came back into fashion and people-first commoners, then elites-went back into the rivers and the thermal springs. In Italy and France, the recovery of Roman and Greek texts stirred a rebirth of hot spring bathing among nobles, a practice that was copied elsewhere in Europe, and which also fomented bathing among the emergent bourgeoisie. ${ }^{37}$ As intellectuals relearned the texts from antiquity about water and health, Europeans adopted the installations and aesthetics of Classical bathing, conserving the wide array of bathing infrastructure and practices-hot and cold pools, steambaths, showers - as well as the rich social, sexual, and spiritual dimensions inherited from the Roman baths and recast in the Middle Ages in Christian terms.

\section{BATHING BY IMMERSION IN MESOAMERICA}

Bathing would once again become acceptable practice in the seventeenth century, but in the 1500 s bathing held deep and powerful connotations of sexual and religious 
danger and was closely monitored. And it was in this context that the Spaniards arrived in the Americas to confront far greater cultural difference and distrust than that which characterized the relation between Christians, Jews, and Moors in Iberia. Like writing, worshipping, and so many other activities carried out by the indigenous people of the Americas, bathing came under intense scrutiny in the New World.

Strange as it might seem, there is no evidence that anyone in Mesoamerica soaked in hot water before the Spanish conquest. It is not that there was no contact with water: on the contrary, bodily contact with water was a central part of daily life for Mexicans before and after contact, and the chronicles written during the early colonial period remark on the cleanliness and bathing habits of the indigenous people. ${ }^{38}$ Díaz del Castillo in his tale of the conquest of Tenochtitlán told of the liberal daily bathing customs of the Aztec elite, and of the barbers who groomed Tlaxcalans. Documents from after the conquest suggest a number of ways that indigenous people washed with water. The indigenous authors of the sixteenth-century Florentine Codex depicted a person sitting by a pool and pouring water over his head and body with a gourd (see Figure 2). In hot lowlands areas such as Veracruz, Yucatan, and the Isthmus of Tehuantepec, people bathed and swam in rivers and other bodies of freshwater. In the Zapotec dictionaries compiled by Spanish priests, for example, there are words for bathing and for soap, which indicates that bathing was done for cleanliness. There was even a word that specifically denoted "waters to bathe in." ${ }^{39}$ Gerónimo de Mendieta, a Franciscan missionary in highland Mexico in the mid-sixteenth century, wrote approvingly of the custom of mothers to bathe their children in the cold water of "streams, rivers and springs, first thing in the morning," which he maintained made them stronger, as Aristotle had said it would. ${ }^{40}$ According to Diego de Landa, a priest traveling in Yucatan, "the Indian women bathed often with cold water like the men, and with little modesty, for they undressed and were naked at the place they went to fetch water." ${ }^{41}$ Mayan women apparently "bathed a lot, simply covering themselves from the view of the men with their hands." ${ }^{2}$ I have found no mention anywhere, however, of indigenous people soaking in hot water.

Despite everyday washing and swimming in cold water, waters were seen to hold dangers, and rivers and creeks held powers that many indigenous people feared. ${ }^{43}$ This was most likely also true for hot thermal springs, for there is no mention by any of the early chroniclers of indigenous people bathing in these waters. It is possible that the practice did exist, but did not make it into the historical record. But there is also no documentary or archeological evidence that people bathed by immersion in waters they heated themselves; no pre-Hispanic bathtubs, for example. If it was a common practice we should expect there to be documentation: nude bathing by immersion in hot water was a particularly troubling activity for priests and government officials engaged in the struggle over the Spanish bathhouses in the sixteenth century, and if there were such activity in the Americas, it would certainly have captured their worried attention. 


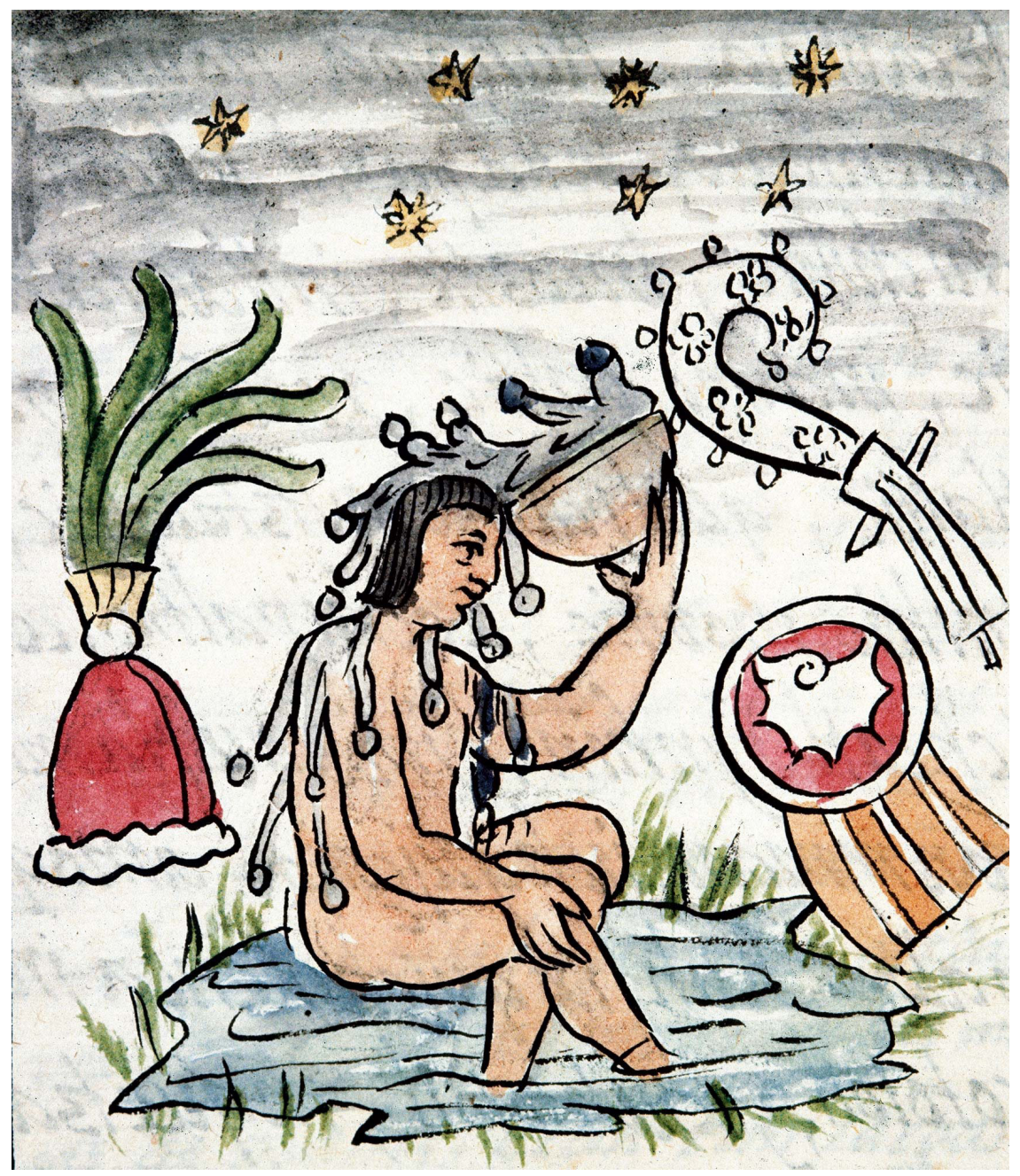

FIGURE 2. An Aztec man taking a bath. Drawing from the Codex Florentino, compiled by Bernardo de Sahagún, c. 1540. Granger Collection, with permission of Age Fotostock.

What makes the absence of any mention of bathing by immersion in hot water even stranger is that hot springs abound in Mexico. Juan de Cárdenas, a doctor born in Seville who lived in Guadalajara at the end of the sixteenth century, remarked upon the "great number of hot springs", and reasoned that their heat was derived from the sulfur that they contain. ${ }^{44}$ Despite these remarks and all the mentions of the cleanliness and bathing habits of indigenous people in Mexico by the Spanish colonizers, there is no record that indigenous people in pre-Colombian 
Mesoamerica went into those hot mineral springs, or that they were a part of indigenous medicine. This absence is especially striking, because there were hot springs in the parts of the Mesoamerican highlands that were most densely populated, and these were put to use for bathing by Spaniards after the conquest. The principal hot springs in the Valley of Mexico were located on a volcanic island that jutted out of the lake east of Tenochtitlán, now a hill known as Peñón de los Baños. In conquest-period documents and indigenous codices, the island with the hot springs is described as an off-limits hunting reserve owned by Aztec nobility, like the forest of Chapultepec, without any reference to bathing or other use of the springs. ${ }^{45}$ This is also the case with other well-known hot springs. Codicespictorial documents produced by indigenous scribes during the contact and early conquest periods-mention the hot springs at Ixtapan de la Sal for the production of salt, not for bathing, and Oaxtepec, Morelos, was known for its royal Aztec botanical garden rather than its hot springs. ${ }^{46}$ The mineral waters of Tehuacán, Puebla, which became important for their therapeutic properties in the colonial period, were used in pre-Hispanic times for irrigation and salt production, as were those of the warm mineral waters in Hierve el Agua, Oaxaca. ${ }^{47}$ Inca rulers soaked in Andean hot springs, but there is no evidence of a similar use of hot springs in Mesoamerica. ${ }^{4}$

Even after Spanish contact there is little record of bathing by immersion in hot water or hot springs. Records point to bathing by Spaniards who, despite the prohibitions on using bathhouses in Granada, built a bathhouse at Peñón de los Baños and, by 1600 , were building similar installations elsewhere. ${ }^{49}$ The sole mention of indigenous practices of bathing by immersion in hot water comes from San Bartolomé Agua Caliente, a town in today's Guanajuato that was founded in 1541 by Fernando de Tapia, a Christianized indigenous leader who allied with the Spaniards in the conquest and colonization of the Bajio. His daughter, Beatriz de Tapia, is credited with providing, in her last will and testament in 1602, the land, springs, and money to build a hospital in San Bartolomé to serve "indios naturales y pobres," a project that was not completed until the late eighteenth century. ${ }^{50}$ It is unclear whether the indigenous people in that region bathed in those hot springs before the Spaniards and their indigenous allies colonized the area, but if they did it is certainly strange that there is no mention of this practice by Spanish priests.

\section{THE TEMAZCAL}

Instead of soaking in hot water, indigenous people in Mesoamerica took steambaths or saunas. In the same paragraph quoted above where he talks about coldwater washing, De Landa goes on to describe the less-common practice of bathing with "hot water and fire," which he says was done "for health reasons rather than cleanliness." ${ }^{51}$ It is clear that this was not bathing by immersion, as De Landa lists two kinds of bathing: washing with cold water, and going to the steambath, or 
temazcal. Washing was more clearly aimed at cleaning the skin, while the temazcal was a therapeutic, medicinal, and spiritual activity with strong social dimensions. The unimportance of bathing by immersion in hot water, naturally or artificially heated, is directly related to the importance of the steambath in Mesoamerica.

The temazcal was an important part of life for Native Americans from the Pacific Northwest to Central America, save for the foragers of the arid lands of northern Mexico and the western United States..$^{52}$ In Mesoamerica-from about Nicaragua to the Tropic of Cancer-people bathed in smallish structures of masonry or adobe (often referred to by anthropologists as "sweatlodges") into which heated stones were placed. Water was then thrown upon the hot rocks to make steam. Sometimes the sweatlodge shared a wall made of volcanic rock with an exterior fire chamber so that the heat of the fire would pass through that rock to the bathing chamber. Water was tossed on that rock to create steam for bathing. Bathers would symbolically enter the underworld when they passed through the door of the temazcal, which in preconquest time in Mesoamerica usually displayed a statue of Tezcatlipoca, the god of healing and the underworld..$^{53}$ Other images of gods were also displayed, including that of Tocitzin, or Teteo Innan, sometimes called "grandmother of the temazcal." ${ }_{54}$ Temazcales have been found in elite and everyday residences in the Mayan region built at least seven hundred years before the arrival of the Spaniards, indicating a deep history of bathing practices and beliefs. ${ }^{55}$ Temazcal steambaths remain an important part of life in indigenous areas of Mesoamerica.

The temazcal was a ubiquitous and multifaceted institution in Mesoamerica that played roles in cleanliness, therapy, socialization, sexuality, religion, and agriculture. $^{56}$ The Spanish, however, understood Native American culture in terms of their own ideas of morality and decency, and they sought to banish sexuality, religion and magic from the temazcal in order to reshape it as a social practice dedicated to health and cleanliness. There are many laudatory mentions by the conquistadores of how well groomed the indigenous people were owing to their frequent washing, but the steambath was barely tolerated and particular religious and sexual practices associated with it were singled out as unacceptably offensive and subject to investigation and eradication. The assault on bathing and bathhouses during the 1500 s in Spain was an assault on the religious, ethnic dimensions that did not conform to the ascendant Christian view of society and culture. When the popularity of bathing returned in the 160os, it was no longer associated with religion and socialization among particular subaltern ethnic groups such as Moors and Jews, but rather with practices of health and cleanliness practiced by the nobility and emergent bourgeoisie, as well as those who emulated them. This turn to cleanliness and health was also imposed on the American temazcal, with one result being the loss of historical knowledge about other facets of bathing, and another the predominance of therapeutic uses. ${ }^{57}$

Sex in the bathhouse was the biggest concern, and what we know about the sexual aspects of using the temazcal comes from official prohibitions, condemnations, 


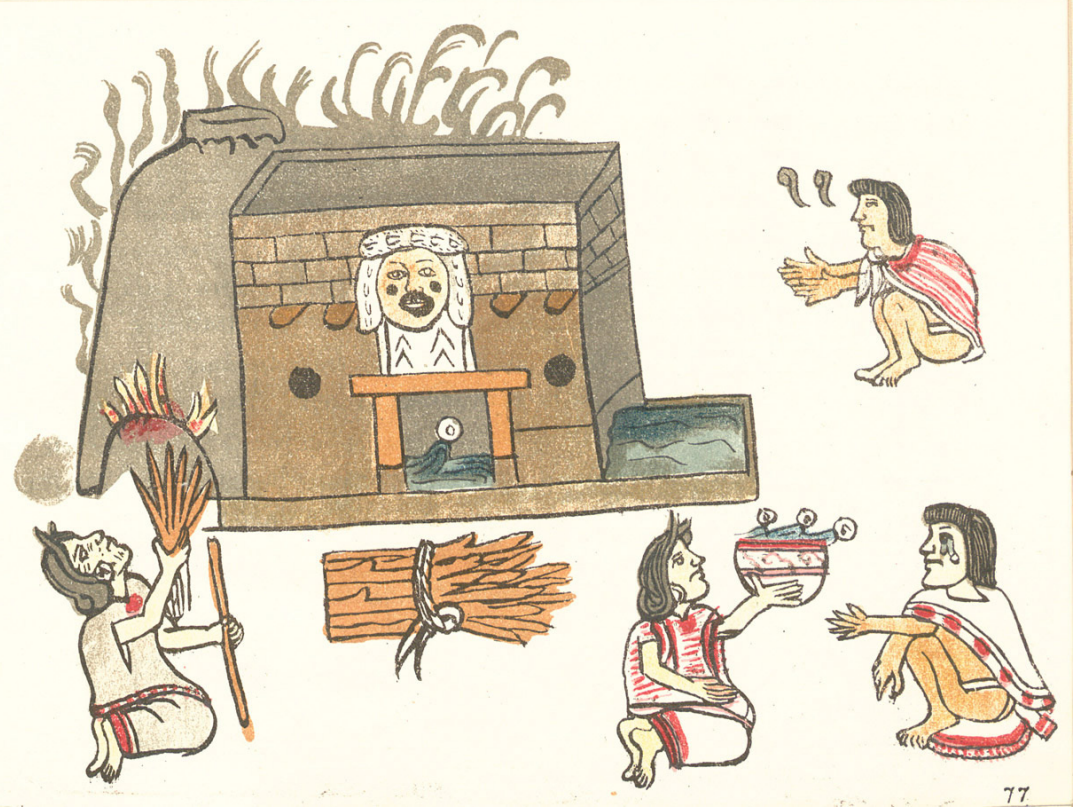

FIgURE 3. A temazcal. Drawing from the Codice Magliabechanio. Source: Wikipedia Commons. https://commons.wikimedia.org/wiki/File:Codex_Magliabechiano_(folio_77r).jpg\#/ media/File:Codex_Magliabechiano_(folio_77r).jpg.

and persecutions. One text tells of "many naked indian men and women committing within [the bath] a great ugliness and $\sin ^{.38}{ }^{8}$ In 1569 a priest penned a series of questions about sexuality in the temazcal, to be asked to Native Americans at confession: "Did you sin with any women [in the bath]? Was one of them your family member or someone you know ... your sister or your sister-in-law? Did you by chance kiss a woman, holding her breasts, touching her, wanting her and coveting her?" ${ }_{59}$ Another priest noted that the temazcal was "illicitly used by men with women, and men with men," surely a problem for those who, operating under heteronormative assumptions, tried to eradicate sexual encounters in the baths by separating men and women. ${ }^{60}$ Despite the efforts of the church and government to banish such practices and limit the function of steambaths to health and cleanliness, temazcales indeed were, and would remain, spaces of unseen and unsanctioned sociality among different ages and sexes of indigenous people. An ethnographer studying the use of the temazcal in Chiapas today notes their continued association with sexuality. ${ }^{61}$

The temazcal proved to be an exceptionally strong institution, and as the colonial encounter progressed, the use of the temazcal extended into other racialethnic groups, including Spaniards who built private temazcales in their houses. ${ }^{62}$ 
Increasingly the concerns about bathing were framed as a problem of public order and health, as well as a problem of $\sin .{ }^{63}$ In 1646 the Crown created an office called the Royal Protomedicato, an official group of doctors and medical experts who were in charge of inspecting pharmacies and apothecaries, reviewing medical publications, examining and licensing doctors, and prosecuting customs and practices that contradicted scientific and Christian principles. ${ }^{64}$ The Protomedicato had neither the responsibility nor the ability to oversee customs among indigenous people, and so mostly focused its attention on the Spanish and casta groups. However, the temazcal, which was strongly associated with indigenous culture although used widely in New Spain, was an important concern of the viceregal government and the Protomedicato in particular. And so, when the Royal Crime Office decried the temazcal for inciting men to engage in sodomy, the viceroy was forced to act. ${ }^{65}$ The viceroy Conde de Monclova (1686-88) decided to keep the temazcales open, but in the subsequent administration of the Conde de Galve (1688-1696) they were closed while two doctors, Ambrosio de la Lima and Joséph de Oliver, conducted a study to determine the social and medical dangers and benefits of this form of bathing. ${ }^{66}$

In the report published by the two doctors in 1692, their scientific opinion about the benefits of bathing was strongly informed by the idea that Spaniards and Indians were different races of humans with different physical constitutions. De la Lima and de Oliver concluded that the temazcales were useful for the wellbeing of indigenous people, in particular, but also for Spaniards and castas, "whatever their color." That said, the doctors suggested that "for Spaniards, water baths would be more useful than temazcales because white people have a more severe temperament" that would be "offended by steambaths." ${ }^{67}$ This advice was informed by humoralism, a theory inherited from the Greeks and Romans which held that bodies - and here races of bodies - were characterized by different balances of blood (air), phlegm (water), yellow bile (fire), and black bile (earth), which produced the particular emotional and physical constitutions of individuals and races.

By reiterating the acceptability of bathing for health and cleanliness, and condemning bathing for social, sexual, and religious purposes, the 1692 study and others published later in the eighteenth century helped reshape quotidian bathing practices and water cultures more generally. Despite the 1692 vindication, and the spread of the steambath throughout society, it continued to hover between acceptance and prohibition, and was an ongoing object of concern for the colonial government. Around 1725, for example, temazcales were prohibited in the indigenous pueblo of San Juan Teotihuacan, causing loud protest, and in 1741 the census ordered by the first viceroy Conde de Revillagigedo counted twenty-four temazcal bathhouses, double the permitted number. ${ }^{68}$ The complicated mix of benefits from curation and cleanliness and dangers of sexuality and sensual exaltation, as well as the fact that the temazcal was by the eighteenth century an accepted activity that extended throughout all levels and groups of colonial society, mobilized constant patrolling of the practice. 


\section{CONCLUSION: COLONIAL WATER CULTURES}

As they rebuilt and expanded Tenochtitlán, transforming it into Mexico City, the capital of New Spain, the Spanish elite slowly replaced the lacustrine system with one modeled on that which they knew back home. It was incremental change in many interrelated aspects of life: the environment, the culture, the economy. Floods devastated the growing city in the second half of the sixteenth century, prompting officials to embark on an enormous, centuries-long project to drain the Valley of Mexico. In carrying out this project they ignored and denied the uses and meanings given to the liquid by indigenous peasants who depended on complex wetland ecologies for their livelihoods, in favor of the notion that water was an input in production and a threat to a city that should not be wet. ${ }^{69}$ Colonial public works extended those erected by the Aztecs to protect Tenochtitlán from flooding and provide freshwater, but they started from different cultural assumptions about the environment and the relation of humans to it and to one another. In confronting the peculiar environment of the Valley of Mexico the Spaniards were guided by a view of nature and humans inherited from scholars who lived in dry places-Hippocrates and Galen, Avicenna, and Pliny-and this view did not lead them to a harmonious and successful adaptation. In the process the Mesoamerican water culture that was relatively well adapted to the environment was dissolved, reworked, and transformed. As Alain Musset puts it, "the battle to control water was as cultural as it was technical."’o

The very method of Spanish rule assured the continuity of indigenous water cultures, however. Like the Aztec rulers before them, the Spanish focused on controlling land and labor and extracting tribute. The indigenous peasant economy was the basis for the reproduction of the labor that enriched the Spaniards, and was left alone in many ways. The Spaniards did not try to eradicate hunting, fishing, and collecting resources, and alongside these basic economic activities, beliefs and ideas concerning water also persisted through the colonial period. ${ }^{71}$ Both Spanish rulers and the indigenous ones before them made herculean efforts to keep water from flooding the island-city and to provide clean freshwater for its expanding population. The Aztecs built levees and raised the city up by filling in the lakebed; the Spaniards lowered the lakewaters by draining the Valley. The indigenous rulers built a kilometers-long aqueduct across the lake to bring clean freshwater from the springs at Chapultepec to the island-city of Tenochtitlán. The Spaniards adopted the same solution, rebuilding the aqueduct to channel new sources of fresh water into the city even as they drained water away from it. ${ }^{72}$ This massive project to drain the Valley and bring in water was carried out by indigenous workers and the Spaniards learned from them.

Quotidian understandings of and engagements with water shifted as well. Indigenous people took steambaths rather than bathe by immersion, and hot mineral springs were apparently not utilized. The temazcal remained important 
in Mesoamerica, spreading as a practice through all social castes and classes, facilitated, perhaps, by a long-standing familiarity with the Moorish steambath among the Spanish that was not entirely negative. But the holistic practice involving religion, sexuality, and ideas about human and agricultural fecundity was narrowed through repression to concentrate on health and cleanliness. On the other hand, in the first century of conquest Europeans started the practice of bathing by immersion in hot water and, in particular, in the hot springs of highland Mexico. This form of bathing, and all its associated European ideas about health and the curative properties of waters, also spread through the different castes and classes of colonial society. By the eighteenth century, both immersion baths and temazcales were common in the bathhouses of Mexico. These colonial baths and bathing practices were, in turn, subject to new forms of scrutiny and regulation in the age of the Enlightenment. 